\title{
Is There a Subjective Well-Being Premium in Voluntary Sector Employment?
}

\begin{abstract}
Previous studies have found that employment in the voluntary sector offers a so-called ‘job satisfaction premium’: despite lower salaries, voluntary sector employees are more satisfied with their jobs than workers in other sectors. This paper examines whether voluntary sector employees also experience a subjective well-being premium. Using data from the UK Annual Population Survey 2012/2013, we find that voluntary sector employees do have higher levels of subjective well-being but this subjective well-being premium is not evenly distributed between men and women. Men score higher on happiness and life satisfaction. However, women in the voluntary sector have lower levels of life satisfaction compared with their counterparts in the public sector. We discuss the implications of our findings for policy and practice in the voluntary sector in the UK.
\end{abstract}

\section{Keywords}

Subjective well-being, gender, employment, voluntary sector, non-profit sector 
'Voluntary sector' ${ }^{1}$ employment is growing in importance in many European countries. In the UK, for example, voluntary sector organisations, charities and other voluntary and community non-profit organisations, account for a substantial and growing share in the provision of public services. The value of government contracts with the voluntary sector has more than tripled from around $£ 2$ billion in 1996/97 to $£ 6.9$ billion ten years later (Public Administration Select Committee, 2008, p.18). Between 1996 and 2005 the voluntary sector workforce grew by $26 \%$, much faster than in the private sector (11\%) and public sector (14\%) (NCVO, 2007). In 2011 an estimated 732,000 individuals (or 2.6\% of the workforce) in the UK worked in the voluntary sector (NCVO, 2013). Similar trends have been observed elsewhere (e.g. see Burger \& Veldheer, 2001; Hammack, 2001; Salamon, 2010).

One of the competitive advantages of the voluntary sector in the market for public service provision is its intrinsically motivated workforce. People working in the voluntary sector derive another kind of utility (value and benefits) from work than just the financial rewards of wages - their intrinsic motivation for such work. Previous studies have focused predominantly on one such type of benefit - the higher job satisfaction that voluntary sector employees are likely to experience compared to workers in other sectors (e.g. Becchetti, Castriota, \& Depedri, 2013; Benz, 2005; Borzaga \& Tortia, 2006; Donegani, McKay, \& Moro, 2012; Francois, 2000; Francois \& Vlassopoulos, 2008; Lee \& Wilkins, 2011). There has been little research into other possible non-monetary benefits of working in the voluntary sector.

In this paper we take a 'spillover' approach to work and life relationships and argue that the premium of working for voluntary organisations extends beyond the work domain and job satisfaction. Drawing on voluntary sector employees' motivation theories, we argue that

\footnotetext{
${ }^{1}$ This is also commonly known as the non-profit sector, or third sector. In the survey on which the analysis is based, this sector comprises those jobs which are 'A charity, voluntary organisation or trust'. The private sector is based on two options: 'a private firm or business, a limited company' or 'A public limited company (plc)'. A wide range of other options comprise the public sector (e.g. 'Central government or civil service' and 'A nationalised industry/state corporation', among others).
} 
voluntary sector employment might also offer a subjective well-being premium. We have chosen to focus on subjective well-being as it is increasingly used by scholars and policy makers as an important indicator of quality of life (Stiglitz, Sen, \& Fitoussi, 2009). Although some studies have shown that job satisfaction is related to subjective well-being, this relationship is only of moderate strength and often inconsistent (Bowling, Eschleman, \& Wang, 2010; Tait, Padgett, \& Baldwin, 1989; Thoresen, Kaplan, Barsky, Warren, \& de Chermont, 2003) and therefore justifies studying subjective well-being as an outcome in its own right.

We ask the following research questions:

What are the differences in the levels of subjective well-being among individuals employed in the voluntary, public and private sectors in the UK?

Is there a subjective well-being premium for voluntary sector employees (after taking into account variations in socio-demographic characteristics across sectors)?

How do working conditions contribute to subjective-wellbeing?

As the voluntary sector workforce in the UK is predominantly female, so we ask whether the subjective well-being premium, if any, applies equally to male and female employees.

We use data from the Annual Population Survey 2012/2013 (APS), a very large representative survey in the UK which now includes several subjective well-being measures. Because there is a large sample of voluntary sector employees it provides us with a rare opportunity to conduct a more complete analysis than many voluntary sector studies are able to. The APS also includes a standard set of demographic variables used to predict subjective well-being, and questions on the type of work that people do and the conditions they work in.

\section{Literature Review}




\section{Job Satisfaction Premium}

To attract and retain high quality staff employers have to offer employees appropriate monetary or non-monetary benefits. A long standing assumption in the voluntary sector literature is that people employed in the voluntary sector receive benefits other than earnings from their work, which often are lower than in the private and public sectors. According to Hansmann (1980) the prohibition of the distribution of profits in voluntary sector organisations requires employees who are motivated more by work itself (e.g. providing a quality public service) than financial rewards. Therefore individuals who have higher levels of intrinsic motivation - those who choose to perform an activity out of a sense of interest in this activity (Porter \& Lawler, 1968) - might be more likely to self-select into voluntary organisations. Voluntary sector employees may also accept lower levels of pay and other financial rewards because they are motivated by a mission: they trust that their efforts are helping to achieve a vision they themselves believe in instead of enriching somebody else (Rose-Ackerman, 1996) or they are willing to donate some of their labour to the production of public good they value highly (Besley \& Ghatak, 2005; Preston, 1989). Indeed some studies show that although the job itself is the main motivator for employees in all three sectors, it is a much more important source of job satisfaction for voluntary sector employees than for employees in other two sectors (Mirvis, 1992; Mirvis \& Hackett, 1983). Similarly Rutherford (2009) found that voluntary sector employees are more likely to say they share the organisation's goals - especially those who are paid below their expected wage for the industry they work in.

Similar arguments have been proposed concerning the differences in motivation and the self-selection process into the public and private sectors (for example, Kim et al., 2013; Moynihan \& Pandey, 2007; Perry \& Hondeghem, 2008; Perry \& Porter, 1982; Steen \& 
Rutgers, 2011; Vandenabeele, 2007). However, any differences between the public and voluntary sectors have, so far, been explored rather less.

It has been argued that as the result of intrinsic motivation voluntary and public sector employees are more likely to experience other kinds of utility from their job than just financial rewards (Francois, 2000; Francois \& Vlassopoulos, 2008). Previous studies have focused mainly on one type of such benefit - higher job satisfaction - and have found job satisfaction to be higher in non-profit organisations than in public and private sector organisations, even in the presence of lower wage levels (e.g. Benz, 2005; Borzaga \& Tortia, 2006; Donegani et al., 2012 ; Lee \& Wilkins, 2011). Moreover individuals who move from the profit to non-profit sector experience an increase in job satisfaction (Becchetti et al., 2013). This advantage has persisted over a long period of time in the UK, covering 19922008 (Donegani et al. 2012), despite apparent variations in overall levels of job satisfaction. However one study found that the job satisfaction premium for voluntary sector workers disappeared after controlling for relative wages (Rutherford, 2009), suggesting that the true picture may be more complex.

\section{Subjective Well-being Premium}

Higher job satisfaction is not the only benefit that individuals with high levels of intrinsic motivation experience. Research shows that higher levels of intrinsic work motivation are associated with other positive outcomes; for example, better job performance and subjective well-being (Burton, Lydon, D'Alessandro, \& Koestner, 2006; Cini, Kruger, \& Ellis, 2013). Therefore we could expect that the benefits of being employed in the voluntary sector would extend beyond job satisfaction. Yet the existing literature on voluntary sector employment has largely overlooked wider benefits that individuals employed in the voluntary sector might derive from their job. 
This paper addresses this gap and focuses on the relationships between working in the voluntary sector and subjective well-being. We propose that the benefits that voluntary sector employees experience might extend beyond the work domain and that therefore voluntary sector employment might relate to higher levels of subjective well-being.

Subjective well-being is commonly defined as ‘a person's cognitive and affective evaluation of his or her life' (Ed Diener, Lucas, \& Shigehiro, 2005, p.63). Subjective wellbeing is a multi-dimensional construct with three facets: cognitive, positive affect and negative affect. The cognitive facet represents what a person thinks of his or her life, how satisfied and fulfilled one finds his or her life. Affective or emotional facet characterises how a person feels about their life (Kahneman, Diener, \& Schwarz, 2003), for example how happy, angry or anxious they usually are. Contrary to a prevalent view, positive and negative feelings about one's life are not at the opposite ends of the same scale, and so therefore they should be treated as different facets (Bradburn, 1969; Huppert \& Whittington, 2003).

Because cognitive, positive and negative affect are three different constructs, which also tend to have different relationships with various predictors and outcomes of subjective well-being, each of these facets needs to be measured to assess subjective well-being comprehensively (Dolan \& Metcalfe, 2012). A person would have high subjective well-being if she is satisfied with her life, thinks that what she does is worthwhile and experiences frequent joy, happiness or other positive emotions. She would rarely experience negative emotions, such as sadness, anxiety and anger (E. Diener \& Suh, 1997).

We expect that employment in the voluntary sector is related to higher levels of subjective well-being among employees because, according to the spillover theory, experiences from one area of life can affect experiences in other life domains (Kabanoff, 1980; Near, Rice, \& Hunt, 1980; Wilensky, 1960). According to this theory experiences at work contribute to satisfaction in non-work domains - for example, family and leisure 
domains - and to subjective well-being in general. The reverse - 'a bad day at the office' also applies.

However, the causality is not always clear. This study is both relatively exploratory given the lack of past research on this topic and the availability of new data, and it's also associational in nature. It is, of course, tempting to infer causal claims. If voluntary sector workers are happier than others, having controlled for differences in their socio-demographic composition and working conditions, there are a number of alternative explanations for this.

The first is that working in the voluntary sector promotes greater life satisfaction. As voluntary sector employees tend to have higher levels of job satisfaction, and job satisfaction has been shown to be positively related - albeit only moderately - to life satisfaction (Bowling et al., 2010; Tait et al., 1989; Thoresen et al., 2003) we would expect that this job satisfaction to some extent might lead to the higher levels of subjective well-being.

The second is that people with higher levels of subjective wellbeing choose to work in this sector. A third possible view is causally reciprocal relationships: i.e. people with higher subjective well-being choose to work in the voluntary sector and in turn, their work there further increases their subjective well-being. It could also be that some spurious factor is at work and the two concepts (employment in the voluntary sector subjective well-being) are unconnected.

With most existing data not addressing this possible connection, and in the absence of feasible field experiments, it is hard to pin down the actual direction of causation. Nevertheless our starting point is that we lack knowledge of the associations between working in the voluntary sector and subjective well-being.

\section{Analytical Model}

Subjective wellbeing levels vary by socio-demographic factors like age, gender, education, income, marital status, health and disability status (Cummins, 2000; Ed Diener, 
2009a; Dolan, Peasgood, \& White, 2008) which are unequally distributed between sectors. In order to accurately access the relationships between voluntary sector employment and subjective well-being, our analyses account for differences in those traits.

In addition we control for a range of work-related factors: working hours, industry, and occupation, place of work, size of workplace, managerial responsibilities and length of employment. These controls will permit us to take into account the differences in working arrangements between various sectors. Control variables also help to separate out the effect that various working conditions have on subjective well-being. Different jobs offer opportunities for satisfaction of needs at different degrees (Warr, 2007), and therefore it follows that some jobs could enhance subjective well-being while others have an adverse effect on it. For example, working in higher occupations is associated with higher life satisfaction and levels of happiness than working in unskilled jobs (Haring, Stock, \& Okun, 1984; Schoon, Hansson, \& Salmela-Aro, 2005).

In our analyses we also look separately at men and women because previous studies have shown that gender is an important mediating factor for relationships between work and subjective well-being. For example, the Office for National Statistics data reveal that in the UK part-time employees have slightly higher life satisfaction than full-time employees (ONS, 2013a). However, when gender differences are considered, men working part-time are less satisfied with their lives than men working full-time while for women the effect of part-time work on wellbeing is varied and depends on their marital status (Schoon et al., 2005).

The effects of work and work status can have varying impacts on life satisfaction for men and women, as demonstrated by a recent study in Germany which showed that holding a managerial position is associated with higher life satisfaction for men but not for women (Trzcinski \& Holst, 2012).

\section{Data and Methods}




\section{Data}

To analyse relationships between employment sector and well-being we used high quality data from the Annual Population Survey (APS) 2012/2013 collected by the Office for National Statistics in the UK (ONS Social Survey Division, 2013). The APS surveys 150,000 households and around 300,000 individuals asking about their housing, employment, education and other subjects. The APS data are collected using both face-to-face and telephone interviews.

This study used a nationally representative sample of 113,690 employed adults aged 16 and over, who lived in residential households in the UK and who reported the sector in which they work. Participants were on average 42 years old $(S D=13)$ and $52 \%$ were women. The response rate for the APS is approximately $50 \%$, therefore to ensure the representativeness to the estimated population of adults in the UK in 2012/13, all analyses presented in this paper are weighted using the well-being weight available in the dataset.

\section{Measurements.}

Outcome variables. The APS includes four questions to monitor subjective well-being in the UK (ONS, 2013a, 2013b):

- Overall, how anxious did you feel yesterday? (measuring the negative affect)

- Overall, how happy did you feel yesterday? (positive affect )

- Overall, how satisfied are you with your life nowadays? (measuring life satisfaction one of the dimensions of the cognitive facet of subjective well-being )

- Overall, to what extent do you feel the things you do in your life are worthwhile? (life fulfilment - a different dimension of the cognitive facet).

Answers to these questions are on a scale of 0 ('not at all') to 10 ('completely'). The questions relate to ‘yesterday’ partly because ‘today’ will be unusual since respondents are being interviewed (Dolan, Layard, \& Metcalfe, 2011; Dolan \& Metcalfe, 2012) . 
Despite some scepticism in the social sciences concerning the validity of self-report data (e.g. see Nisbett \& Wilson, 1977), these subjective well-being measurements have been found to have good convergent validity: they converge with other types of assessment including expert ratings based on in-depth interviews, experience sampling in which feelings or level of satisfaction are reported at random moments in everyday life, participants' reports of positive and negative events in their lives, smiling and the reports of family and friends (Dolan et al., 2011; Pavot \& Diener, 1993; Pavot, Diener, Colvin, \& Sandvik, 1991; Sandvik, Diener, \& Seidlitz, 1993). While levels of reliability for subjective well-being measures are lower than those typically found for so called 'objective' well-being variables (e.g. income, level of education), they are sufficiently high to support much of the research that is currently being undertaken on subjective well-being, particularly in studies where group means are compared (Krueger \& Schkade, 2008; Pavot \& Diener, 1993).

Sector of employment. The APS participants are asked what type of organisation they are working for from a list of several options. Respondents who said they work for a charity, voluntary organisation or trust were coded as ' 0 ' 'Voluntary sector' ( $3 \%$ of the sample, $n=3,491)$. All 33,754 (30\%) respondents who reported that they work in a range of public sector organisations (e.g. central government, civil service, local government, including police, fire services, schools or colleges, university, health authority, armed forces) were classified as ' 1 ' Public sector' ${ }^{1}$. Respondents $(67 \%, n=76,445)$ who reported that they work for a private firm or business or a limited or public company were coded as '2'.

\section{Data analysis methods}

For bivariate analyses we used ANOVA tests. To analyse the multivariate relationships between sectors and subjective well-being, we estimated a series of ordinary least squares (OLS) models in which the dependent variable was, in turn, each of the four subjective wellbeing measures. 
Although in a strict sense, the well-being scales are ordinal (a higher value means higher wellbeing, but the 'gaps' between scores are not necessarily equivalent), the use of OLS in our study is justified as other studies have shown that treating the well-being variables either as ordinal or as interval leads to the same conclusions (e.g.Ed Diener, Diener, \& Diener, 1995, p.861). Similarly, Ferrer-i-Carbonell and Frijters (2005) and Frey and Stutzer (2009) have compared OLS and models for ordinal data and concluded that the substantive conclusions do not change. Diener and Tov (2012) and OECD (2013) came to a similar conclusion.

We tested the robustness of our OLS models against the violation of the interval scale assumption by running both OLS and ordered logit and probit regressions (which treat wellbeing data as ordinal variables). The conclusions from the OLS and ordered logit and probit estimates were identical. In this paper we report the OLS estimates as the interpretation of them is more straightforward and therefore they are likely to be more widely understood by readers. The ordered logit and probit estimates are available on request.

\section{Results}

\section{Sector, Gender and Subjective Well-being: Bivariate Relationships}

Table 1 presents weighted statistics on subjective well-being. It indicates that the relationships between sector and subjective well-being varied by dimension of subjective well-being and were moderated by gender.

The only subjective well-being dimension that had statistically significant sector variations for both men and women was life fulfilment. On average, voluntary sector male employees had the highest levels of fulfilment: private sector employees scored 0.36 points and the public sector employees 0.11 points less. Among women the highest level of fulfilment was among women working in the public sector, followed by women in the 
voluntary sector. The differences in the scores were small but significant. Subjective wellbeing is affected by a multitude of factors. We would expect each of the factors to contribute only a little, and expect the differences in the scores to be relatively small.

Table 1 also shows that women, but not men, in the voluntary sector were also significantly less satisfied with their lives than women in other two sectors: they scored 0.23 less points less than female employees in the public sector and 0.16 less points than private sector women.

\section{$<$ TABLE $1>$}

\section{Socio-demographic Characteristics, Working conditions and Subjective Well-being}

Bivariate analyses also indicated that, as we predicted, subjective well-being was significantly related to a wide range of socio-demographic and work-related factors which also varied significantly by sector. Therefore in order to distil the possible sector effects on well-being it was necessary to control for all these factors.

We found that in general, voluntary sector and public sector employees were similar in their socio-demographic characteristics and types of jobs, and different from private sector employees. A typical voluntary and public sector employee tended to be a woman $(64 \%$ and $63 \%$ of all employees in the sector, respectively), aged over 35 (71\% and 72\%, respectively), with a degree (43\% and 45\%), married or in a partnership (48\% and 55\%), separated, widowed or divorced (18\% and 15\%). In comparison, private sector employees were significantly $(\mathrm{p}<0.001)$ more likely to be men $(60 \%$ of all employees in the sector), younger, single (43\%) and less likely to have a degree (26\%). Voluntary and public sector employees were also on average nearly twice as likely (12\% and $10 \%$ respectively) to have a worklimiting disability as in the private sector (6\%). All these socio-demographic characteristics had statistically significant relationships at $\mathrm{p}<0.01$ with all subjective well-being dimensions. 
Voluntary and public sector employees were also employed in similar jobs: most voluntary sector (72\%) and public sector (87\%) workers worked in public administration, education and health services. This was significantly different from the private sector where $85 \%$ of employees were working in other industries. Similarly, most voluntary and public sector employees (68\% and 73\% respectively) were employed in five higher occupations: managerial, professional, associate professional, administrative and skilled trades. This is in contrast to the private sector where only half of workers were in these five occupations. The special exception was care and leisure service occupations, where the proportion of voluntary sector men and women working in them (16\% and $25 \%)$ was much higher than in the private (2\% and 14\%) and public sector (7\% and 19\%). Gender segregation by industry and occupation was observed in all sectors.

Despite high levels of qualifications and working in skilled occupations voluntary sector employees had the lowest average pay: on average a male voluntary sector employee earned $£ 313$ a week, much less than a public sector male employee (£378) and less than a private sector employee (£363). This was different for female employees: women in the voluntary sector earned $£ 241$ a week, which was less than women in the public sector (£273) but more than women in the private sector (£228).

Despite the above similarities in jobs to the public sector, voluntary sector employees were more likely to face atypical working conditions: at home or from home, on nonpermanent contracts and in part-time work. Voluntary sector workers were also more likely to report that they have been employed with the current employer for between one and four years and least likely to report working for ten more years. In all three sectors women were considerably less likely to work full-time than men. While $55 \%$ of voluntary, $54 \%$ of private and $59 \%$ of public sector women worked full-time, these proportions were much higher among men $-82 \%, 87 \%$ and $88 \%$, respectively. The voluntary sector also had the highest 
proportion of workers, both men (5\%) and women (8\%), who did part-time work because they could not find a full-time job. In the private sector these proportions were $4 \%$ and $6 \%$ but in the public sector $-3 \%$ and $4 \%$. Finally, nearly two thirds of voluntary sector employees, both men and women (62\% and 64\%, respectively) were working in small (50 employees or less) organisations. This was in contrary to the public sector where only $23 \%$ of men and 34\% of women reported working in a small organisations. All above working conditions and socio-demographic characteristics were significantly related to all dimensions of subjective well-being at $\mathrm{p}<0.05$.

\section{Regression Results}

Employment sector and well-being. According to Table 2 when socio-demographic characteristics, type of job and working conditions were taken into account, there was indeed a subjective well-being premium for workers in the voluntary sector; however, the subjective well-being premium was not equally pronounced for both men and women.

$$
>\text { Table } 2 \text { about here }<
$$

The regression analyses (see Table 3) suggest that both men and women working in the voluntary sector on average reported significantly higher levels of fulfilment in life than the private sector employees (with 0.36 and 0.16 points difference, respectively), only voluntary sector men, not women, scored significantly higher (0.22 points difference) on fulfilment than their public sector counterparts. Voluntary sector men also scored significantly higher (0.20 points difference) on happiness than private sector men but for women the sector of employment did not make any difference for their happiness. On average the life satisfaction levels among voluntary sector male employees were significantly higher than among the private and public sector employees ( 0.22 and 0.16 points difference), but women in the voluntary sector reported on average 0.13 points lower life satisfaction levels than women in the public sector. 
$<$ Table 3>

Working conditions and subjective well-being. Table 3 suggests that it was not only the sector which mattered for subjective well-being: working conditions and sociodemographic characteristics did too. Independently of the sector of employment, men and women, working in public administration, educational and health services reported significantly higher levels of fulfilment with their lives than workers in other industries. Working in care and leisure services, in general, had a negative effect for male but a positive effect for female subjective well-being. Men in professional occupations reported significantly higher levels of fulfilment, happiness and life satisfaction than men in the care and leisure services. Similarly, men in managerial, skilled trades and skilled operative occupations also reported higher levels of life satisfaction. For women, most of the occupational differences were observed for the fulfilment facet of well-being: women in elementary, sales and customer services, administrative, associate professional and managerial occupations had significantly lower levels of fulfilment than women working in the care and leisure service occupations.

Part-time employees, both men and women, who had chosen to work part-time (or who worked part-time because they were students or disabled), were happier, more fulfilled and more satisfied than full-time workers. In contrast, men and women who worked part-time because they could not find a full-time job were less satisfied with their lives than full-time employees. Women working part-time involuntarily also reported lower levels of happiness and fulfilment.

Table 3 also suggests that working at home had a positive effect on all aspects of women's well-being but men working at home were less anxious than men working at an employer's premises. 
Length of service with one’s current employer also predicted subjective well-being. Men who had been employed for 5-9 years were less anxious while women employed for similar periods were more satisfied with their lives that those who had been employed for less than a year. Permanency of employment contract was important only for male employees: those on permanent contracts were happier and had higher levels of fulfilment and life satisfaction than men on non-permanent contracts. Long term employment (10+ years) mattered only for women's life satisfaction.

Managerial status was significantly related with subjective well-being, but, similarly to previous studies - more so for men than women. Men holding managerial positions had higher levels of fulfilment and life satisfaction but also higher levels of anxiety. Having a managerial (or supervisory) position had a positive effect only on women's fulfilment levels.

Table 3 also indicates that women are happier and less anxious and men are more fulfilled working in small organisations.

\section{Discussion and conclusions}

In this paper, we asked whether there is a subjective well-being premium associated with employment in the voluntary sector in the UK. We find that independently of their socio-demographic characteristics and working conditions, voluntary sector employees experience a small but significant subjective well-being premium; however, this premium is not equally distributed between men and women. While both men and women in the voluntary sector experience higher levels of fulfilment than private sector employees, only men have higher levels of happiness and life satisfaction. Women in the voluntary sector have lower life satisfaction than their public sector counterparts.

We suggest that these higher levels of fulfilment among voluntary sector employees are consistent with theories that assume that individuals who are motivated by providing public good and services self-select into voluntary sector organisations which in turn provide them 
with opportunities to do work that brings fulfilment and satisfaction (Besley \& Ghatak, 2005; Hansmann, 1980; Preston, 1989; Rose-Ackerman, 1996). However, it is also worth noting the similarity of levels of life fulfilment and happiness for women working in the public sector to those in the voluntary sector (no statistically significant difference in the models), and indeed that women working in the public sector had the highest levels of life satisfaction. So, whilst there is a general advantage of working in the voluntary sector for outcomes among men, for women such advantages are restricted to comparisons with the private sector. The public service motivation concept, discussed above (Kim et al 2013), that may help to select women into the public sector appears at least as strong as any voluntary sector ethos - though not for men, for whom the voluntary sector seemed to offer the greatest levels of fulfilment and satisfaction compared with both public and service sectors

As for the gender differences in happiness and life satisfaction, we are limited in the firm conclusions we can reach with the data we have, but one possible area of explanation (which needs further investigation) is that men in the third sector might benefit in some ways from their minority status (only 36\% of third sector employees in our sample were men, compared to $60 \%$ in the private sector). Research suggests that men working in femaledominated environments tend to have faster career progression than women because of assumptions that they are better leaders, have more skills and are more career orientated (e.g. Williams, 1991). Although Teasdale et al. (2011) found that women in the voluntary sector were less likely to face gender inequality than women in the private sector, they are still less likely than men to hold a managerial position and more likely to receive lower pay.

We also explored the contribution of working conditions to subjective well-being. Again we find that work in industries that provide public good is related to higher levels of fulfilment. We also find, similarly to Wooden (2009) that atypical working conditions, such as part-time work and work at home, are related to higher well-being but more so for women 
than men, and the match between employees' working time preferences and part-time work is an important determinant of well-being. One possible explanation is that atypical working conditions might offer employees a higher degree of autonomy and control which are found to be positively related to subjective well-being (Sheldon, Ryan, \& Reis, 1996) . Moreover we found that the longer an employee has worked for their employer, the higher their wellbeing, suggesting that employment permanence and job security might be important contributors to employees’ subjective well-being. Moreover, more satisfied people may be less likely to seek alternative employment.

The major limitation of this study is that it cannot address sufficiently the question of causal direction - largely because we rely on cross-sectional data. A longitudinal study would provide insights into the causal mechanisms that link employment and subjective-wellbeing and would reduce the threat that some of our findings could be due to unobserved heterogeneity in omitted variables, for example, personality traits, social networks which might not be equally distributed across sectors. There is also a perhaps obvious variable that is not in our statistical analysis - that of job satisfaction. This variable does not appear in the UK Annual Population Survey. However, whilst some might regard this as a problem - the omission of job satisfaction from the regression model could mean that the 'voluntary sector effect' will appear to be higher in our model, compared with a model in which job satisfaction was included, the previous research shows that job satisfaction has only a weak and often inconsistent relationship to life satisfaction and other well-being variables (Bowling et al., 2010; Tait et al., 1989; Thoresen et al., 2003). Therefore while it is plausible that job satisfaction acts as a mediating variable, its effect is likely to be weak.

Despite the limitations, our findings may have some useful policy and practice implications. Aggregate subjective well-being estimates can be used for policy purposes in three ways: to monitor progress, to inform policy design and for policy appraisal (Ed Diener, 
2009b; Dolan \& Metcalfe, 2012; Dolan \& White, 2007). We have taken the first step - that of monitoring.

Our findings on wellbeing in the voluntary sector workforce can be used to make judgements at sector level on how voluntary sector organisations as employers are doing in terms of maintaining, increasing and contributing to the well-being of their employees and consequently to the well-being of the nation. This is particularly important during a recession when there are concerns about levelling down the quality of employment in the public and voluntary sectors towards that of the private sector (Cunningham, 2008; Cunningham \& James, 2009; Grimshaw \& Rubery, 2012).

Such monitoring at the policy and sector level is important because subjective wellbeing is related to several important life outcomes. For instance, higher levels of subjective well-being are associated with better health, longer life and a more positive attitude to others (Chida \& Steptoe, 2008; Lyubomirsky, King, \& Diener, 2005).

Our research indicates that while well-being levels for voluntary sector males are still the highest across all sectors, policymakers should urgently address the issue of subjective well-being for women employed in the voluntary sector, especially with regard to their life satisfaction.

On a broader policy level, there is a rising demand among policymakers for knowledge about social conditions that foster subjective well-being (e.g. see Bache \& Reardon, 2013; Stiglitz et al., 2009). Our research provides some indication of which employment-related factors, including which sector of employment, contribute to the subjective well-being of employees.

On a practical level, the subjective well-being of employees is also likely to affect the functioning of organisations in terms of the levels of sickness absence, retention, employee engagement and user satisfaction (for example see a overview by Robertson \& Cooper, 
2011). Managers in voluntary sector organisations can therefore benefit from knowledge about how the subjective well-being levels of their employees compare to employees in other sectors and which working conditions relate to well-being. Our findings suggest that the match of working conditions and employees’ preferences and length of service are important for employees’ well-being, therefore the current voluntary sector practices of short-term contracts, zero hours and part-time work (Cunningham, 2008; Cunningham \& James, 2009), often a result of needing to compete for service delivery contracts with other voluntary and private sector providers, in the long term seem likely to have a detrimental effect on the retention of workers and the quality of their service.

Empirical data on aggregate subjective well-being levels could potentially be used to estimate the value of voluntary sector, similarly to Fujiwara et al. (2013) who used subjective well-being data to estimate the value of volunteering.

While we believe that our study provides some fresh insight into sector differences in well-being, it also opens up avenues for further inquiry. The findings suggest that it is critical to analyse the working experiences of men and women separately while looking at working conditions in the voluntary sector.

\section{Acknowledgements}

The support of the Economic and Social Research Council (ESRC), the Office for Civil Society (OCS) and the Barrow Cadbury UK Trust is gratefully acknowledged. The work was part of the programme of the joint ESRC, OCS Barrow Cadbury Third Sector Research Centre. The authors would like to thank Dr. Matthew Bennett and the anonymous reviewers for their helpful comments on previous drafts of this article. 


\section{Notes}

1. A sensitivity analysis established that there were no statistically significant differences in the levels of well-being between people working in the armed forces and 'other kind of organisations' and in the rest of public sector. Therefore these two types of organisations were included under 'public sector'. 


\section{Tables}

Table 1. Bivariate association between sectors and subjective well-being, by gender, UK, 2012/2013

\begin{tabular}{|c|c|c|c|c|c|c|}
\hline & \multicolumn{3}{|c|}{ Men } & \multicolumn{3}{|c|}{ Women } \\
\hline & $\begin{array}{l}\text { Voluntary } \\
\text { sector } \\
\text { Mean (SD) }\end{array}$ & $\begin{array}{l}\text { Private } \\
\text { sector } \\
\text { Mean (SD) }\end{array}$ & $\begin{array}{l}\text { Public } \\
\text { sector } \\
\text { Mean (SD) }\end{array}$ & $\begin{array}{l}\text { Voluntary } \\
\text { sector } \\
\text { Mean (SD) }\end{array}$ & $\begin{array}{l}\text { Private } \\
\text { sector } \\
\text { Mean (SD) }\end{array}$ & $\begin{array}{l}\text { Public } \\
\text { Sector } \\
\text { Mean (SD) }\end{array}$ \\
\hline $\begin{array}{l}\text { Subjective } \\
\text { well-being }\end{array}$ & & & & & & \\
\hline Happiness & 7.31 (1.89) & 7.29 (1.82) & $7.36(1.85)$ & 7.40 (1.91) & $7.30(2.02)$ & 7.40 (2.09) \\
\hline Anxiety & $2.90(2.51)$ & $2.84(2.42)$ & $2.91(2.54)$ & 3.28 (2.69) & 3.06 (2.73) & $3.11(2.88)$ \\
\hline $\begin{array}{l}\text { Fulfilment*** } \\
\text { Life }\end{array}$ & 7.98 (1.47) & 7.62 (1.39) & 7.87 (1.36) & 8.05 (1.39) & 7.80 (1.49) & $8.08(1.42)$ \\
\hline satisfaction* & $7.56(1.46)$ & $7.54(1.42)$ & $7.58(1.45)$ & $7.43(1.63)$ & 7.59 (1.57) & 7.63 (1.59) \\
\hline $\mathrm{N}=$ & 1,104 & 42,746 & 10,999 & 2,387 & 33,699 & 22,755 \\
\hline
\end{tabular}


Table 2. Sector of employment and subjective well-being. A brief summary of key findings from the regression analyses.

Subjective well-being dimensions

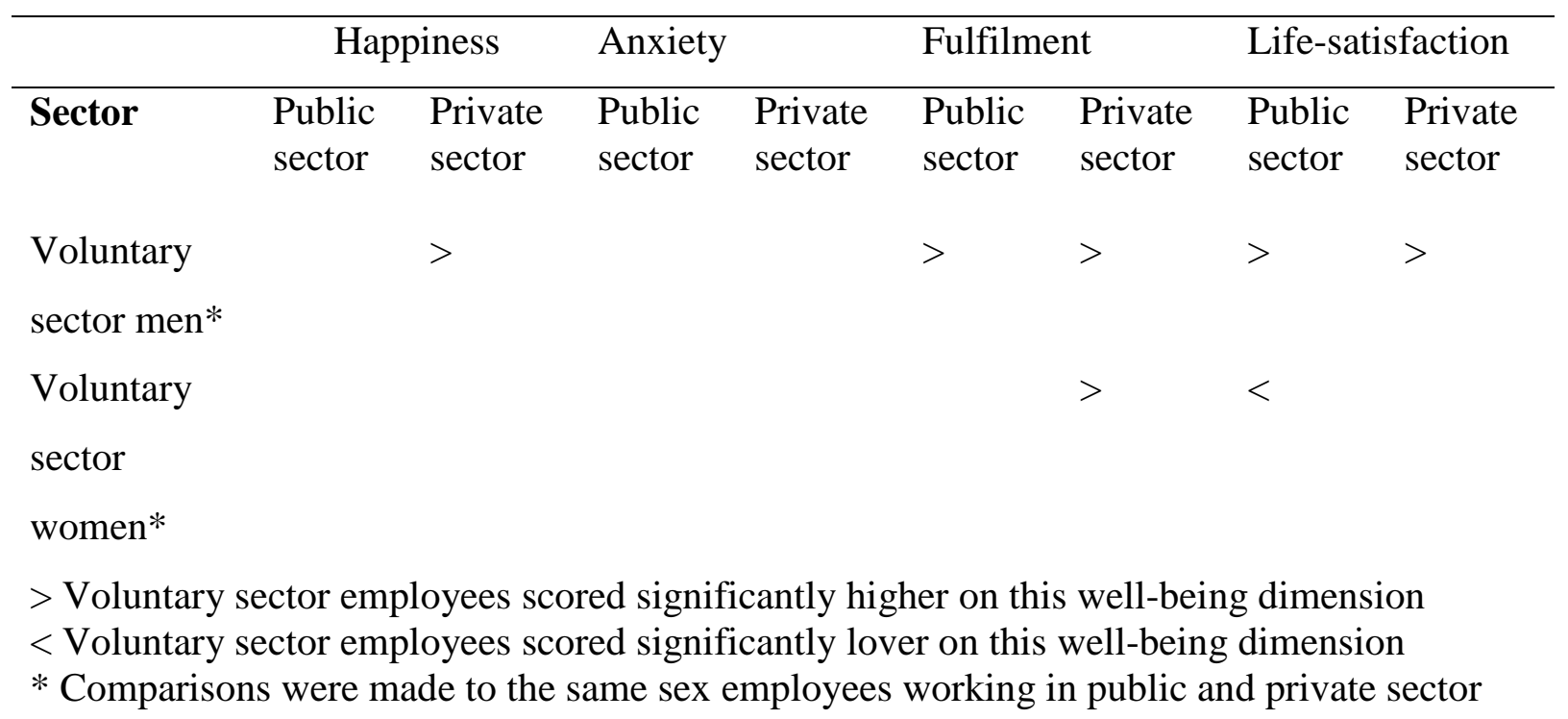


Table 3. Estimated coefficients from a series of linear regression models of subjective well-being by sector of employment, socio-demographic characteristics and key working condition indicators, UK, 2012/2013

\begin{tabular}{|c|c|c|c|c|c|c|c|c|}
\hline & \multicolumn{4}{|c|}{ Model 1: Men } & \multicolumn{4}{|c|}{ Model 2: Women } \\
\hline & Happiness & Anxiety & Fulfilment & Life & Happiness & Anxiety & Fulfilment & Life \\
\hline & $\begin{array}{l}\text { Coef. } \\
\text { (SE) }\end{array}$ & $\begin{array}{l}\text { Coef. } \\
\text { (SE) }\end{array}$ & $\begin{array}{l}\text { Coef. } \\
\text { (SE) }\end{array}$ & $\begin{array}{l}\text { Coef. } \\
\text { (SE) }\end{array}$ & $\begin{array}{l}\text { Coef. } \\
\text { (SE) }\end{array}$ & $\begin{array}{l}\text { Coef. } \\
\text { (SE) }\end{array}$ & $\begin{array}{l}\text { Coef. } \\
\text { (SE) }\end{array}$ & $\begin{array}{l}\text { Coef. } \\
\text { (SE) }\end{array}$ \\
\hline \multicolumn{9}{|l|}{ Sector (Voluntary sector) } \\
\hline Private sector & $-0.2 *$ & 0.24 & $-0.36 * * *$ & $\begin{array}{l}-0.22 * * * \\
(0.08)\end{array}$ & $\begin{array}{l}-0.12 \\
(0.07)\end{array}$ & $\begin{array}{l}0.03 \\
(010)\end{array}$ & $-0.16 * * *$ & 0.04 \\
\hline Public sector & -0.11 & 0.23 & $-0.22 * * *$ & $-0.16 * *$ & -0.01 & -0.09 & -0.02 & $0.13^{*}$ \\
\hline Net income per week $(00 \mathrm{~s} £$ ) & $0.04 * * *$ & $\begin{array}{l}(0.13) \\
-0.02\end{array}$ & $0.034 * * *$ & $0.06 * * *$ & $\begin{array}{l}(0.07) \\
0.00\end{array}$ & $(0.09)$ & $(0.05)$ & $(0.05) * 0$ \\
\hline Netincemenor & $(0.01)$ & $(0.01)$ & $(0.01)$ & $(0.01)$ & $(0.02)$ & $(0.02)$ & $(0.01)$ & $(0.01$ \\
\hline Net income per week (00s $£$ ) squared & $\begin{array}{l}-0.01 * * \\
(0.01)\end{array}$ & $\begin{array}{l}0.01 \\
(0.01)\end{array}$ & $\begin{array}{l}-0.01 * * * \\
(0.00)\end{array}$ & $\begin{array}{l}-0.01 * * * \\
(0.00)\end{array}$ & $\begin{array}{l}0.01 \\
(0.01)\end{array}$ & $\begin{array}{l}0.01 \\
(0.01)\end{array}$ & $\begin{array}{l}-0.01 \\
(0.00)\end{array}$ & $\begin{array}{l}-0.01 * \\
(0.00)\end{array}$ \\
\hline & \multirow{7}{*}{$\begin{array}{l}-0.13 \\
(0.07) \\
-0.24 * * * \\
(0.08) \\
-0.21^{* *} \\
(0.08) \\
0.01) \\
(0.09)^{2} \\
0.51 * * * \\
(0.12)\end{array}$} & \multirow{7}{*}{$\begin{array}{l}0.25^{* *} \\
(0.10) \\
0.42^{* * *} \\
(0.10) \\
0.38^{* * *} \\
(0.11) \\
0.14 \\
(0.11) \\
-0.44^{* *} \\
(0.17)\end{array}$} & \multirow{7}{*}{$\begin{array}{l}-0.11 \\
(0.06) \\
-0.16^{* *} \\
(0.06) \\
-0.17 * * \\
(0.06) \\
0.05 \\
(0.07) \\
0.51 * * * \\
(0.09)\end{array}$} & \multirow{7}{*}{$\begin{array}{l}-0.21^{* * *} \\
(0.06) \\
-0.48 * * * \\
(0.06) \\
-0.51^{* * *} \\
(0.06) \\
-0.23^{* * *} \\
(0.07) \\
0.21 * * \\
(0.09)\end{array}$} & \multirow{7}{*}{$\begin{array}{l}-0.16^{*} \\
(0.07) \\
-0.25^{* * *} \\
(0.07) \\
-0.23^{* * *} \\
(0.07) \\
-0.09 \\
(0.08) \\
0.31 * * \\
(0.12)\end{array}$} & \multirow{7}{*}{$\begin{array}{l}0.17^{*} \\
(0.09) \\
0.27 * * \\
0.09) \\
0.27^{* *} \\
(0.10) \\
0.30^{* *} \\
(0.11) \\
-0.04 \\
(0.18)\end{array}$} & \multirow{7}{*}{$\begin{array}{l}-0.05 \\
(0.05) \\
-0.10 * \\
(0.05) \\
-0.14^{* *} \\
0.05 \\
(0.06) \\
0.06 \\
0.36^{* * *} \\
(0.09)\end{array}$} & \multirow{7}{*}{$\begin{array}{l}-0.31 * * * \\
(0.05) \\
-0.51 * * * \\
(0.05) \\
-0.56 * * * \\
(0.05) \\
-0.44 * * * \\
(0.06) \\
-0.10 \\
(0.09)\end{array}$} \\
\hline & & & & & & & & \\
\hline $35-44$ & & & & & & & & \\
\hline $45-54$ & & & & & & & & \\
\hline $55-64$ & & & & & & & & \\
\hline & & & & & & & & \\
\hline $65^{+}$ & & & & & & & & \\
\hline $\begin{array}{l}\text { Education (No degree) } \\
\text { Degree }\end{array}$ & $-0.10 *$ & $0.25 * * *$ & $-0.17 * * *$ & $-0.21 * * *$ & -0.01 & $0.29 * * *$ & $-0.11 * * *$ & $-0.12 * * *$ \\
\hline & $(0.04)$ & $(0.05)$ & $(0.03)$ & $(0.03)_{* * *}$ & $(0.04)$ & $(0.05)$ & $(0.03)$ & $(0.0 \overline{3})$ \\
\hline Married/civil partnership & $\begin{array}{l}0.28 * * * \\
(0.04)\end{array}$ & $\begin{array}{l}0.01 \\
(0.05)\end{array}$ & $\begin{array}{l}0.26 * * * \\
(0.03)\end{array}$ & $\begin{array}{l}0.32 * * * \\
(0.03)\end{array}$ & $\begin{array}{l}0.37 * * * \\
(0.04)\end{array}$ & $\begin{array}{l}-0.02 \\
(0.05)\end{array}$ & $\begin{array}{l}0.22 * * * \\
(0.03)\end{array}$ & $\begin{array}{l}0.40 * * * \\
(0.03)\end{array}$ \\
\hline Separated/widowed/divorced & -0.05 & 0.05 & 0.03 & $-0.16^{* * *}$ & -0.07 & $0.20 * * *$ & -0.05 & $-0.24 * * *$ \\
\hline Subjective health status & $0.43^{*} * *$ & $\begin{array}{l}(0.08) \\
-0.48 * * *\end{array}$ & $0.37 * * *$ & $0.43^{*} * *$ & $0.054 * *$ & $\begin{array}{l}(0.06) \\
-0.63 * * *\end{array}$ & $0.37 * * *$ & $0.51 * * *$ \\
\hline Disability status (No disability) & $(0.02)$ & $(0.03)$ & $(0.02)$ & $(0.02)$ & $(0.02)$ & $(0.03)$ & $(0.02)$ & $(0.02)$ \\
\hline Work limiting disability & \multirow{3}{*}{$\begin{array}{l}-0.18^{* *} \\
(0.06) \\
0.01 \\
(0.07)\end{array}$} & \multirow{3}{*}{$\begin{array}{l}0.27 * * * \\
(0.09) \\
0.21 * \\
(0.09)\end{array}$} & \multirow{3}{*}{$\begin{array}{l}-0.18^{* * *} \\
(0.06) \\
0.10 * \\
(0.05)\end{array}$} & \multirow{2}{*}{$\begin{array}{l}-0.36 * * * \\
(0.06) \\
-0.03 \\
(0.05)\end{array}$} & \multirow{2}{*}{$\begin{array}{l}-0.14^{*} \\
(0.06) \\
0.10 \\
(0.06)\end{array}$} & \multirow{3}{*}{$\begin{array}{l}0.32 * * * \\
(0.08) \\
0.02 \\
(0.08)\end{array}$} & \multirow{3}{*}{$\begin{array}{l}-0.02 \\
(0.04) \\
0.08^{*} \\
(0.04)\end{array}$} & \multirow{3}{*}{$\begin{array}{l}-0.13^{* * *} \\
(0.04) \\
0.06 \\
(0.04)\end{array}$} \\
\hline Disability without work limit. & & & & & & & & \\
\hline Industry (Public adm.,educ.\&health) & & & & \multirow{4}{*}{$\begin{array}{l}0.10 \\
(0.07) \\
0.03 \\
(0.05)\end{array}$} & \multirow{4}{*}{$\begin{array}{l}0.04 \\
(0.07) \\
0.06 \\
(0.05)\end{array}$} & & & \\
\hline Other services & \multirow{3}{*}{$\begin{array}{l}0.06 \\
(0.09) \\
0.03 \\
(0.06)\end{array}$} & \multirow{3}{*}{$\begin{array}{l}0.07 \\
(0.13) \\
-0.05 \\
(0.08)\end{array}$} & \multirow{3}{*}{$\begin{array}{l}0.07 \\
(0.07) \\
-0.15^{* * *} \\
(0.04)\end{array}$} & & & \multirow{3}{*}{$\begin{array}{l}0.09 \\
(0.10) \\
-0.05 \\
(0.06)\end{array}$} & \multirow{3}{*}{$\begin{array}{l}-0.05 \\
(0.05) \\
-0.16 * * * \\
(0.03)\end{array}$} & \multirow{3}{*}{$\begin{array}{l}0.07 \\
(0.05) \\
0.02 \\
(0.03)\end{array}$} \\
\hline Other industries & & & & & & & & \\
\hline Occupation (Care \&Leisure services) & & & & & & & & \\
\hline Elementary & 0.17 & $\begin{array}{l}-0.09 \\
-0.13)\end{array}$ & -0.14 & -0.02 & 0.07 & $\begin{array}{l}-0.07 \\
(0.09)\end{array}$ & $-0.22 * * *$ & 0.04 \\
\hline Operatives & 0.10 & -0.05 & 0.02 & $0.19 *$ & 0.14 & -0.15 & -0.09 & 0.11 \\
\hline Sales, customer service & 0.15 & $(0.13)$ & $\begin{array}{l}(0.08) \\
-0.06\end{array}$ & 0.07 & $(0.13)$ & $\begin{array}{l}(0.18) \\
-0.11\end{array}$ & $\begin{array}{l}(0.09) \\
-0.16 * *\end{array}$ & $\begin{array}{l}(0.10) \\
0.04\end{array}$ \\
\hline & $(0.12)$ & $(0.15)$ & $(0.09)$ & $(0.09)$ & $(0.06)$ & $(0.09)$ & $(0.05)$ & $(0.05)$ \\
\hline
\end{tabular}


Skilled trades

Administrative

Associate professional

Professional

Managerial

Working hours (Full-time)

Part-time (choice)

Part-time (Could not find full-time)

Part-time (Student, or disabled)

Place of work (At employer's premises)

At home

Home as a base

Length of service with this employer ( $<1$ year)

1-4 year

5-9 year

$10+$

Permanency of job (Non-permanent) Permanent

Managerial responsibilities (None)

Supervisor

Manager

Size of workplace (Large 250+)

Medium (50-249)

Small $(<50)$

Intercept

Adjusted $\mathrm{R}^{2}$

\begin{tabular}{|c|c|c|c|}
\hline $\begin{array}{l}0.19 \\
(0.10) \\
0.04 \\
(0.11) \\
0.19 \\
(0.10) \\
0.20^{*} \\
(0.10) \\
0.16 \\
(0.10)\end{array}$ & $\begin{array}{l}-0.01 \\
(0.13) \\
0.14 \\
(0.14) \\
0.01 \\
(0.12) \\
0.00 \\
(0.12) \\
0.10 \\
(0.13)\end{array}$ & $\begin{array}{l}0.09 \\
(0.07) \\
-0.15 \\
(0.08) \\
0.03 \\
(0.07) \\
0.17 * \\
(0.07) \\
0.12 \\
(0.07)\end{array}$ & $\begin{array}{l}0.20 * \\
(0.09) \\
0.08 \\
(0.09) \\
0.15 \\
(0.08) \\
0.27 * * * \\
(0.08) \\
0.20^{*} \\
(0.09)\end{array}$ \\
\hline $\begin{array}{l}0.20 * * \\
(0.08) \\
0.01 \\
(0.10) \\
0.36 * * * \\
(0.11)\end{array}$ & $\begin{array}{l}0.05 \\
(0.11) \\
0.13 \\
(0.13) \\
0.28 \\
(0.17)\end{array}$ & $\begin{array}{l}0.28 * * * \\
(0.06) \\
-0.14 \\
(0.08) \\
0.38 * * * \\
(0.09)\end{array}$ & $\begin{array}{l}0.31 * * * \\
(0.06) \\
-0.28^{* * *} \\
(0.09) \\
0.30 * * * \\
(0.09)\end{array}$ \\
\hline $\begin{array}{l}0.06 \\
(0.09) \\
0.10 \\
(0.07)\end{array}$ & $\begin{array}{l}-0.27 * \\
(0.14) \\
-0.20^{*} \\
(0.09)\end{array}$ & $\begin{array}{l}-0.05 \\
(0.07) \\
0.07 \\
(0.05)\end{array}$ & $\begin{array}{l}0.04 \\
(0.07) \\
0.07 \\
(0.05)\end{array}$ \\
\hline $\begin{array}{l}-0.08 \\
(0.06) \\
-0.05 \\
(0.06) \\
-0.09 \\
(0.06)\end{array}$ & $\begin{array}{l}-0.12 \\
(0.08) \\
-0.22 * * \\
(0.08) \\
-0.11 \\
(0.08)\end{array}$ & $\begin{array}{l}-0.07 \\
(0.04) \\
-0.03 \\
(0.05) \\
-0.04 \\
(0.04)\end{array}$ & $\begin{array}{l}0.02 \\
(0.04) \\
0.07 \\
(0.05) \\
0.07 \\
(0.04)\end{array}$ \\
\hline $\begin{array}{l}0.25 * * * \\
(0.08)\end{array}$ & $\begin{array}{l}-0.16 \\
(0.11)\end{array}$ & $\begin{array}{l}0.13^{*} \\
(0.06)\end{array}$ & $\begin{array}{l}0.17 * * \\
(0.07)\end{array}$ \\
\hline $\begin{array}{l}0.03 \\
(0.05) \\
0.06 \\
(0.04)\end{array}$ & $\begin{array}{l}0.11 \\
(0.07) \\
0.16^{* * *} \\
(0.06)\end{array}$ & $\begin{array}{l}0.08^{*} \\
(0.04) \\
0.18^{* * *} \\
(0.03)\end{array}$ & $\begin{array}{l}-0.02 \\
(0.04) \\
0.14 * * * \\
(0.03)\end{array}$ \\
\hline $\begin{array}{l}0.01 \\
(0.04) \\
0.05 \\
(0.04) \\
5.53 * * * \\
(0.20) \\
\end{array}$ & $\begin{array}{l}-0.01 \\
(0.05) \\
0.07 \\
(0.05) \\
4.13^{* * *} \\
(0.24)\end{array}$ & $\begin{array}{l}0.04 \\
(0.03) \\
0.1^{* * *} \\
(0.03) \\
6.52^{* * *} \\
(0.13)\end{array}$ & $\begin{array}{l}0.01 \\
(0.03) \\
0.01 \\
(0.03) \\
5.93^{* * *} \\
(0.15)\end{array}$ \\
\hline 0.04 & 0.03 & 0.08 & 0.10 \\
\hline
\end{tabular}

0.20
$(0.11)$
0.02
$0.05)$
0.02
$(0.06)$
0.02
$0.06)$
0.05
$(0.07)$
$0.08^{*}$
$(0.04)$
$-0.22 * * *$
$(0.08)$
0.10
$(0.08)$
$0.22 * *$
$(0.09)$
-0.04
$(0.09)$
-0.01
$(0.05)$
-0.01
$(0.05)$
0.06
$(0.05)$
-0.11
$(0.06)$
0.08
$(0.04)$
$0.04)$
$(0.04)$
-0.01
$(0.04)$
$0.08 * *$
$(0.04)$
$5.61^{* * *}$
$(0.14)$
0.06

$\begin{array}{ll}-0.32 * & -0.06 \\ (0.16) & (0.09)\end{array}$

$\begin{array}{lll}(0.16) & (0.09) & (0.09)\end{array}$

$(0.07) \quad(0.04) \quad(0.04)$

$0.13 \quad-0.09 * \quad 0.03$

$\begin{array}{lll}0.08) & (0.04) & (0.04) \\ 0.10 & 0.04 & 0.08\end{array}$

$0.107)$

$(0.07) \quad(0.04)$

$\begin{array}{lll}0.11 & -0.09 & 0.00 \\ 0.05) & (0.05)\end{array}$

$\begin{array}{lll}-0.07 & 0.17 * * * & 0.11 * * *\end{array}$

$(0.05)$

0.17

$0.28^{*}$

$(0.03)$

$-0.26^{* * *}$

$0.19 * * *$

(0.06)

(0.03)

$(0.06)$

$(0.06)$

$-0.34 * * * \quad 0.27 * * * \quad 0.22 * * *$

(0.12) (0.07)

$-0.03 \quad 0.13$

(0.06)

0.01

(0.07)

$-0.04 \quad-0.03$

$(0.07) \quad(0.04)$

$-0.08 \quad-0.01$

$(0.07) \quad(0.04)$

$(0.07) \quad(0.04)$

0.04

$0.08 *$

$(0.04)$

(0.04)

$-0.11 \quad-0.03$

$-0.03$

$\begin{array}{ll}(0.05) & (0.05)\end{array}$

$\begin{array}{ccc}-0.01 & 0.09 * * * & 0.02 \\ (0.06) & (0.03) & (0.03)\end{array}$

$\begin{array}{lll}(0.06) & (0.03) & (0.03) \\ 0.03 & 0.13 * * * & 0.05\end{array}$

$\begin{array}{lll}(0.06) & (0.03) & (0.03)\end{array}$

$\begin{array}{lll}0.01 & 0.01 & -0.02\end{array}$

$\begin{array}{lll}0.01 & (0.03) & (0.03)\end{array}$

$\begin{array}{ccc}-0.10^{*} & 0.05 & 0.05 \\ (0.05) & (0.03) & 0.03)\end{array}$

$\begin{array}{llll} & (0.05) & (0.03) & (0.03) \\ (0.14 * * & 5.1 * * * & 6.86^{* * *} & 5.94 * * *\end{array}$

0.06

0.11 


\section{References}

Bache, I., \& Reardon, L. (2013). An idea whose time has come? Explaining the rise of well-being in British politics. Political Studies, 61(4), 898-914.

Becchetti, L., Castriota, S., \& Depedri, S. (2013). Working in the for-profit versus not-for-profit sector: what difference does it make? An inquiry on preferences of voluntary and involuntary movers. Industrial and Corporate Change.

Benz, M. (2005). Not for the profit, but for the satisfaction? Evidence on worker well-being in non-profit firms. Kyklos, 58(2), 155-176.

Besley, T., \& Ghatak, M. (2005). Competition and incentives with motivated agents. American Economic Review, 95(3), 616-636.

Borzaga, C., \& Tortia, E. (2006). Worker motivations, job satisfaction, and loyalty in public and nonprofit social services. Nonprofit and Voluntary Sector Quarterly, 35(2), 225-248.

Bowling, N. A., Eschleman, K. J., \& Wang, Q. (2010). A meta-analytic examination of the relationship between job satisfaction and subjective well-being. Journal of Occupational and Organizational Psychology, 83(4), 915-934.

Bradburn, N. M. (1969). The structure of psychological well-being. Chicago: Aldine.

Burger, A., \& Veldheer, V. (2001). The growth of the nonprofit sector in the Netherlands. Nonprofit and Voluntary Sector Quarterly, 30(2), 221-246.

Burton, K. D., Lydon, J. E., D'Alessandro, D. U., \& Koestner, R. (2006). The differential effects of intrinsic and identified motivation on well-being and performance: prospective, experimental, and implicit approaches to self-determination theory. Journal of Personality and Social Psychology, 91(4), 750.

Chida, Y., \& Steptoe, A. (2008). Positive psychological well-being and mortality: a quantitative review of prospective observational studies. Psychosomatic Medicine, 70(7), 741-756.

Cini, F., Kruger, S., \& Ellis, S. (2013). A model of intrinsic and extrinsic motivations on subjective well-being: the experience of overnight visitors to a national park. Applied Research in Quality of Life, 8(1), 45-61.

Connolly, S., \& Gregory, M. (2009). The part-time pay penalty: earnings trajectories of British women. Oxford Economic Papers, 61 (suppl 1), i76-i97.

Cummins, R. A. (2000). Personal income and subjective well-being: A review. Journal of Happiness Studies, 1(2), 133-158.

Cunningham, I. (2008). A race to the bottom? Exploring variations in employment conditions in the voluntary sector. Public Administration, 86(4), 10331053.

Cunningham, I., \& James, P. (2009). The outsourcing of social care in Britain: what does it mean for voluntary sector workers? Work, Employment \& Society, 23(2), 363-375.

Diener, E. (2009a). Subjective well-being. In The science of well-being (pp. 11-58): Springer.

Diener, E. (2009b). Well-being for public policy: Oxford University Press.

Diener, E., Diener, M., \& Diener, C. (1995). Factors predicting the subjective well-being of nations. Journal of Personality and Social Psychology, 69(5), 851 - 864.

Diener, E., Lucas, R. E., \& Shigehiro, O. (2005). Subjective well-being: the science of happiness and life satisfaction. In C. R. Snyder \& S. J. Lopez (Eds.), Handbook of Positive Psychology. New York: Oxford University Press.

Diener, E., \& Suh, E. (1997). Measuring quality of life: Economic, social, and subjective indicators. Social indicators research, 40(1-2), 189-216. 
Diener, E., \& Tov, W. (2012). National accounts of well-being. In Handbook of social indicators and quality of life research (pp. 137-157): Springer.

Dolan, P., Layard, R., \& Metcalfe, R. (2011). Measuring subjective well-being for public policy. Retrieved 24.09, 2013, from http://eprints.Ise.ac.uk/35420/1/measuring-subjective-wellbeing-for-public-policy.pdf

Dolan, P., \& Metcalfe, R. (2012). Measuring subjective wellbeing: recommendations on measures for use by national governments. Journal of social policy, 41(2), 409-427.

Dolan, P., Peasgood, T., \& White, M. (2008). Do we really know what makes us happy? A review of the economic literature on the factors associated with subjective well-being. Journal of Economic Psychology, 29(1), 94-122.

Dolan, P., \& White, M. P. (2007). How can measures of subjective well-being be used to inform public policy? Perspectives on Psychological Science, 2(1), 71-85.

Donegani, C. P., McKay, S., \& Moro, D. (2012). A dimming of the "warm glow"? Are non-profit workers in the UK still more satisfied with their jobs than other workers? Advances in the Economic Analysis of Participatory \& Labor-Managed Firms, 13, 313-342.

Francois, P. (2000). "Public service motivation" as an argument for government provision. Journal of Public Economics, 78(3), 275-299.

Francois, P., \& Vlassopoulos, M. (2008). Pro-social motivation and the delivery of social services. CESifo Economic Studies, 54(1), 22-54.

Fujiwara, D., Oroyemi, P., \& McKinnon, E. (2013). Well-being and civil society: estimating the value of volunteering using subjective wellbeing data. London: HM Treasury and Department for Work and Pensions.

Grant, L., Yeandle, S., Buckner, L., \& Britain, G. (2005). Working below potential: women and part-time work: Equal Opportunities Commission.

Grimshaw, D., \& Rubery, J. (2012). The end of the UK's liberal collectivist social model? The implications of the coalition government's policy during the austerity crisis. Cambridge Journal of Economics, 36(1), 105-126.

Hammack, D. C. (2001). Introduction: growth, transformation, and quiet revolution in the nonprofit sector over two centuries. Nonprofit and Voluntary Sector Quarterly, 30(2), 157-173.

Hansmann, H. B. (1980). The role of nonprofit enterprise. The Yale Law Journal, 89(5), 835-901.

Haring, M. J., Stock, W. A., \& Okun, M. A. (1984). A research synthesis of gender and social class as correlates of subjective well-being. Human Relations, $37(8), 645-657$.

Huppert, F. A., \& Whittington, J. E. (2003). Evidence for the independence of positive and negative well-being: Implications for quality of life assessment. British Journal of Health Psychology, 8(1), 107-122.

Kabanoff, B. (1980). Work and Nonwork: A review of Models, Methods and Findings. Psychological Bulletin, 88(1), 60-77.

Kahneman, D., Diener, E., \& Schwarz, N. (2003). Well-being: The foundations of hedonic psychology: Russell Sage Foundation.

Kim, S., Vandenabeele, W., Wright, B. E., Andersen, L. B., Cerase, F. P., Christensen, R. K., et al. (2013). Investigating the structure and meaning of public service motivation across populations: Developing an international instrument and addressing issues of measurement invariance. Journal of Public Administration Research and Theory, 23(1), 79-102.

Krueger, A. B., \& Schkade, D. A. (2008). The reliability of subjective well-being measures. Journal of Public Economics, 92(8/9), 1833-1845.

Lee, Y. Y., \& Wilkins, V. M. (2011). More similarities or more differences? Comparing public and nonprofit managers' job motivations. Public Administration Review, 71(1), 45-56. 
Lyubomirsky, S., King, L., \& Diener, E. (2005). The benefits of frequent positive affect: Does happiness lead to success? Psychological Bulletin, 131(6), 803.

Mirvis, P. H. (1992). The quality of employment in the nonprofit sector: An update on employee attitudes in nonprofits versus business and government. Nonprofit Management and Leadership, 3(1), 23-41.

Mirvis, P. H., \& Hackett, E. J. (1983). Work and work force characteristics in the nonprofit sector. Monthly Lab. Rev., 106, 3.

Moynihan, D. P., \& Pandey, S. K. (2007). The role of organizations in fostering public service motivation. Public Administration Review, 67(1), 40-53.

NCVO. (2007). The UK Voluntary Sector Workforce Almanac 2007. London: NCVOo. Document Number)

NCVO. (2013). UK Voluntary Sector Workforce Alamanac 2013. London: NCVO.

Near, J. P., Rice, R. W., \& Hunt, R. G. (1980). The Relationship Between Work and Nonwork domains: A Review of Empirical Research. Academy of Management Review, 5, 415-?

Nisbett, R. E., \& Wilson, T. D. (1977). Telling more than we can know: Verbal reports on mental processes. Psychological review, 84(3), 231.

OECD. (2013). OECD Guidelines on Measuring Subjective Well-being: OECD Publishing.

ONS. (2013a). Personal Well-being in the UK 2012/2013. London: ONS,.

ONS. (2013b). What matters most to personal well-being? Retrieved 10.09, 2013, from http://www.ons.gov.uk/ons/rel/wellbeing/measuring-nationalwell-being/what-matters-most-to-personal-well-being-in-the-uk-/index.html

ONS Social Survey Division. (2013). Annual Population Survey: Subjective Well-being, April 2012-March 2013 (2nd ed.). Colchester, Essex: UK Data Archive.

Pavot, W., \& Diener, E. (1993). Review of the satisfaction with life scale. Psychological assessment, 5(2), 164.

Pavot, W., Diener, E. D., Colvin, C. R., \& Sandvik, E. (1991). Further validation of the Satisfaction with Life Scale: Evidence for the cross-method convergence of well-being measures. Journal of Personality assessment, 57(1), 149-161.

Perry, J. L., \& Hondeghem, A. (2008). Motivation in Public Management: The Call of Public Service: The Call of Public Service: Oxford University Press.

Perry, J. L., \& Porter, L. W. (1982). Factors Affecting the Context for Motivation in Public Organizations1. Academy of Management Review, 7(1), 89-98.

Porter, L. W., \& Lawler, E. E. I. (1968). Managerial attitudes and performance. Homewood, IL: Irwin-Dorsey.

Preston, A. E. (1989). The nonprofit worker in a for-profit world. Journal of Labor Economics, 7(4), 438-463.

Public Administration Select Committee. (2008). Public services and the third sector: rhetoric and reality. London: The Stationery Office,.

Robertson, I., \& Cooper, C. L. (2011). Well-being: productivity and happiness at work. Basingstoke: Parlgrave Macmillan.

Rose-Ackerman, S. (1996). Altruism, nonprofits, and economic theory. Journal of Economic Literature, 34(2), 701-728.

Rutherford, A. (2009). In search of the "warm glow": Estimating pay and job satisfaction in the private, public and voluntary sectors. Paper presented at the International Labour Process Conference.

Salamon, L. M. (2010). Putting the civil society sector on the economic map of the world. Annals of Public and Cooperative Economics, 81(2), 167-210.

Sandvik, E., Diener, E., \& Seidlitz, L. (1993). Subjective well-being: the convergence and stability of self-report and non-self-report measures. Journal of Personality 61, 317-342. 
Schoon, I., Hansson, L., \& Salmela-Aro, K. (2005). Combining work and family life: Life satisfaction among married and divorced men and women in Estonia, Finland, and the UK. European Psychologist, 10(4), 309.

Sheldon, K. M., Ryan, R., \& Reis, H. T. (1996). What makes for a good day? Competence and autonomy in the day and in the person. Personality and Social Psychology Bulletin, 22, 1270-1279.

Steen, T. P. S., \& Rutgers, M. R. (2011). The double-edged sword: public service motivation, the oath of office and the backlash of an instrumental approach. Public management review, 13(3), 343-361.

Stiglitz, J. E., Sen, A., \& Fitoussi, J.-P. (2009). Report by the commission on the measurement of economic performance and social progress: OECD.

Tait, M., Padgett, M. Y., \& Baldwin, T. T. (1989). Job and life satisfaction: A reevaluation of the strength of the relationship and gender effects as a function of the date of the study. Journal of Applied Psychology, 74(3), 502.

Teasdale, S., McKay, S., Phillimore, J., \& Teasdale, N. (2011). Exploring gender and social entrepreneurship: women's leadership, employment and participation in the third sector and social enterprises. Voluntary Sector Review, 2(1), 57-76.

Thoresen, C. J., Kaplan, S. A., Barsky, A. P., Warren, C. R., \& de Chermont, K. (2003). The affective underpinnings of job perceptions and attitudes: a meta-analytic review and integration. Paper presented at the 17th Annual Conference of the Society for Industrial and Organizational Psychology, Toronto, ON, Canada.

Trzcinski, E., \& Holst, E. (2012). Gender differences in subjective well-being in and out of management positions. Social Indicators Research, 107(3), 449463.

Vandenabeele, W. (2007). Toward a public administration theory of public service motivation: An institutional approach. Public management review, 9(4), 545-556.

Warr, P. (2007). Work, happiness, and unhappiness: Psychology Press.

Wilensky, H. L. (1960). Work, careers, and social integration. International Social Science Journal, 12, 553-560.

Williams, C. L. (1991). Gender differences at work: Women and men in nontraditional occupations: University of California Press.

Wooden, M., Warren, D., \& Drago, R. (2009). Working time mismatch and subjective well-being. British Journal of Industrial Relations, 47(1), $147-179$. 